\title{
The Impact of Macroeconomic Indicators on Islamic Insurance Demand in Indonesia
}

\author{
Salahuddin El Ayyubi ${ }^{1}$, Widyastutik ${ }^{2}$, Anditta $^{3}$
}

\begin{abstract}
This research aimed to determine the development of the Islamic insurance industry in Indonesia and analyze the influence of macroeconomic indicators on Islamic insurance demand in Indonesia. Ordinary Least Square (OLS) was used in this research with monthly time series data from January 2014 to December 2016. The results of this research indicated that the variables of money supply, interest rate, GDP per capita, and education had a positive (significant) effect on the Islamic insurance demand in Indonesia. Moreover, the inflation variable and dependency ratio had a negative (significant) effect on the Islamic insurance demand in Indonesia.
\end{abstract}

Keywords: Islamic Insurance, OLS, Macroeconomic Variables

\begin{abstract}
Abstrak. Penelitian ini bertujuan untuk melihat perkembangan industri asuransi Islam di Indonesia dan menganalisis pengaruh indikator makroekonomi terhadap permintaan akan asuransi Islam. Penelitian ini menggunakan Ordinary Least Square (OLS) dengan rangkaian data bulanan dari Januari 2014 sampai Desember 2016. Penelitian mengindikasikan bahwa variable penawaran uang, tingkat suku bunga, GDP per kapita, dan pendidikan berdampak positif (signifikan) terhadap permintaan akan asuransi Islam di Indonesia. Selanjutnya, variabel inflasi dan rasio dependensi berdampak negatif (signifikan) terhadap permintaan tersebut.
\end{abstract}

Kata kunci: Asuransi Islam, OLS, Variabel Makroekonomi

\footnotetext{
1,2,3 Bogor Agricultural University

E-mail: ${ }^{1}$ 22djibran@gmail.com, ${ }^{2}$ widyastutik_ipb@yahoo.com, ${ }^{3}$ iseanditta@gmail.com
} 


\section{Introduction}

The insurance industry is one of the non-bank financial industry with important roles in the economic sector of a country. This role is related to its ability as the public reception of a transfer of risk as well as the collector and absorber institution of accumulated public funds. This concept complies with several empirical studies conducted in Asian countries showing that the insurance industry has been one of the pillars of economic growth (Hwang \& Greenford, 2005).

The results of empirical studies by Hwang and Gao (2003) and Hwang and Greenford (2005) show that the growth of the insurance industry in China contributed significantly to the country's macroeconomic development. According to studies by Beck and Levine (2004) and Arena (2006), in countries with high growth rates, the insurance industry would positively affect the production, saving, and accumulated investment capital factors.

Indonesia, as the fourth most populous country in the world, had a rapid growth of the insurance industry. This sector was growing as the GDP growth rate from 2011 to 2016 grew by $5.02 \%$. The growth occurred in all business fields, which the highest growth was achieved by the Financial and Insurance Services grew by $8.90 \%$ (BPS, 2017).

Figure 1. The Real GDB Growth Rate of Indonesia 2011-2016 (Billion)

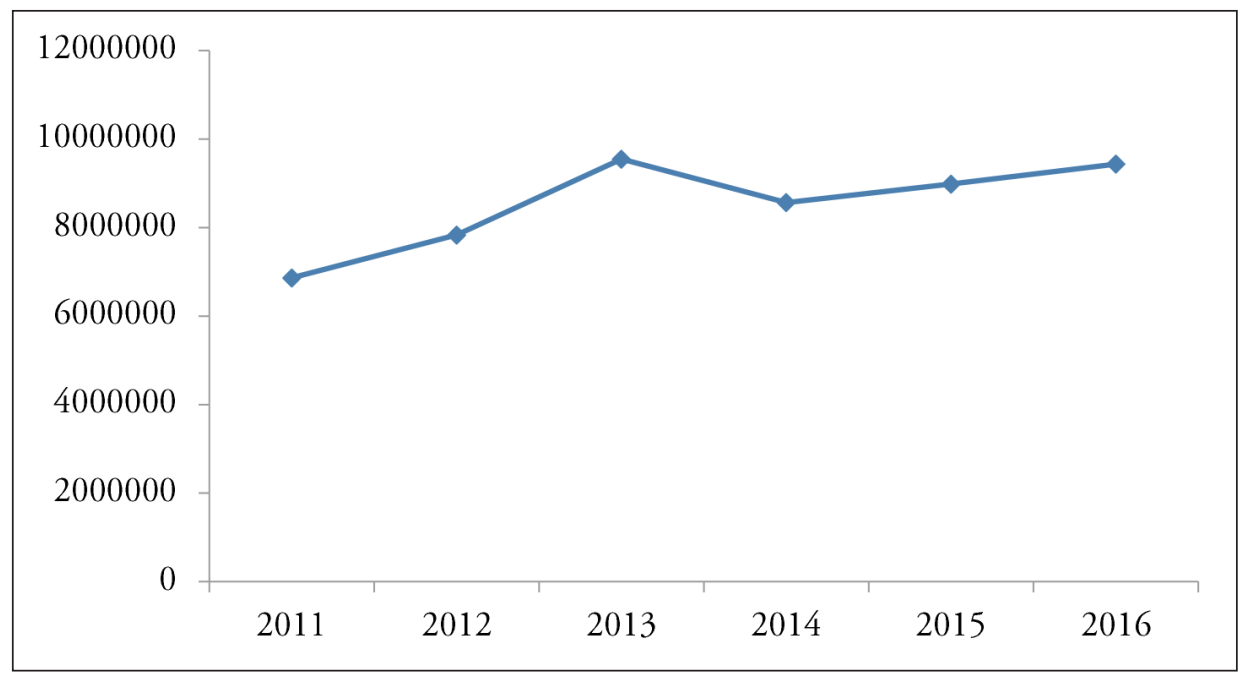

Source: BPS (2016) 
Islamic insurance sector in Indonesia was marked by the establishment of PT Syarikat Takaful Indonesia on 24 February 1994. This establishment was initiated by the Indonesian Association of Muslim Intellectuals (ICMI/Ikatan Cendekiawan Muslim Indonesia) through Abdi Bangsa Foundation, Muamalat Tbk Bank, Syarikat Tafakul Malaysia, PT Asuransi Jiwa Tugu Mandiri, Ministry of Finance, as well as several Indonesian Muslim business people.

Table 1. The Growth of Insurance and Reinsurance Companies with Sharia Principles(units)

\begin{tabular}{lcc}
\hline \multicolumn{1}{c}{ Information } & Q1 2015 & Q1 2016 \\
\hline Sharia life insurance company & 3 & 5 \\
Sharia general insurance company & 2 & 4 \\
Sharia unit of life insurance company & 18 & 19 \\
Sharia unit of general insurance company & 23 & 24 \\
Sharia unit of reinsurance company & 3 & 3 \\
\hline Total & 49 & 55 \\
\hline
\end{tabular}

Source: Indonesian Sharia Insurance Association (2016)

Table (1) shows the number of Sharia Insurance and reinsurance companies with sharia principles. As of 31 March 2016, there were 55 companies consisting of 5 sharia life insurance companies, 4 sharia general insurance companies, 19 sharia unit of life insurance companies, 24 sharia unit of general insurance companies, and 3 sharia unit of reinsurance companies. The number of Sharia Insurance companies increased compared to the previous year. By 2015 the number insurance companies, insurance units, and reinsurance units increased from 49 companies to 55 companies in the first quarter of 2016 (AASI, 2016). This indicated that the Sharia Insurance industry was in demand by the public.

The presence of Sharia Insurance becomes an alternative protection model for Muslims who want insurance products and operational systems that are free from gambling elements (maishir), uncertainty elements (gharar), and usury elements. The concept of Islamic insurance is based on takaful, a combination of responsibility with the fraternity among fellow insurance participants. Therefore, all insurance participants already have intention since the beginning in the form of consent to make financial donations as a charity (tabarru). 
Sharia Insurance growth continued to increase each year during the 2011-2015 period. The evidence was the increase of total assets up to 23640 billion Rupiahs in 2015 (AASI, 2016). However, according to OJK (Otoritas Jasa Keuangan/Financial Services Authority), the market share of Indonesian Sharia Insurance was still very limited, which was only $0.095 \%$. This implied that there was a lot of insured spaces and potentials. Whereas the growth of middle-class society in Indonesia was high, insurance need was supposed to increase (Kasali, 2013). In accordance with the theory of need (Maslow, 2003), when a person's primary and secondary needs were met, then he/she would meet his tertiary needs. In 2003, the number of middleincome population in Indonesia was only 37.7\%. However, in 2010, Indonesia's middle class increased to 134 million people or $56.5 \%$ of the population (World Bank, 2013). The middle class grew seven million each year, so the World Bank assessed that the growth of Indonesia middle class was very fast. This growth leads to a surge in consumption which boosted economic growth in various sectors.

Several previous studies and theoretical analyzes indicate that the insurance demand function is a representation of several indicators, including (1) insurance penetration, the ratio of insurance premiums to the level of Gross Domestic Product (Beck, 2002); (2) insurance density, the ratio of insurance premiums to population (Ward \& Zurberegg, 2000); (3) insurance in private saving, the ratio of insurance premiums to the amount of public savings (Beck, 2002).

The amount of consumption or demand for Islamic insurance is affected by macroeconomic conditions. Hari (2013) states that the demand for Islamic insurance is positively affected by GDP, financial development, society education level, and SBIS rate. The demand for Islamic insurance is also negatively affected by inflation. According to Prihantoro, Basuki, and Iskandar (2013), economic and demographic factors are significantly affected the function of insurance demand in Indonesia. The influence of macroeconomic factor is indicated by the positive influence of GDP growth, interest rate, and financial growth, as well as the negative influence of inflation rate and dependency ratio.

A study conducted by Arena (2006) indicates that there is a causal relationship between macroeconomic growth and insurance development. The study was conducted by applying a panel method to 56 countries using historical data for 28 years (1976-2004). The main variable used by Arena (2006) referred to Outreville's (1996) research, including (1) macroeconomic factors, consisting of the level of gross domestic product, inflation rate, and interest rate of public savings; (2) demographic factors, consisting of education level and urbanization level. Nesterova (2008) shows that the function of insurance demand is significantly influenced by macroeconomic 
variables and demographic variables. While the institutional variables consisted of political stability and efficiency and also government corruption is not significantly affected the insurance demand.

Research by Ginting (2015) shows that the function of general insurance demand is significantly affected by macroeconomic variables. The research results indicate that the GDP, money supply, and interest rate variables have a positive influence on general insurance demand in Indonesia, while the inflation variables have a negative influence on the general insurance demand. This research utilized secondary data in time series from 2006 to 2013 and cointegration regression model with the least-squares method.

The economy affects insurance demand in Indonesia. A good economic growth might be reflected by a good macroeconomic variable (Djaelani, 2015). A good macroeconomic condition reflects the increase in Indonesia's income per capita, enabling people to buy insurance products. Former studies mostly analyzed the effect of macroeconomic variables on demand for conventional insurance. Therefore, it is necessary to conduct research to analyze the effect of macroeconomic variables on demand for Islamic insurance in Indonesia.

\section{Hypothesis}

Based on the theory and previous research, the hypothesis of this research was:

H1: Money supply (M2) had a positive effect (significant) on the demand for Islamic insurance in Indonesia.

$\mathrm{H} 2$ : Inflation had a negative effect (significant) on the demand for Islamic insurance in Indonesia.

H3: SBIS (Sertifikat Bank Indonesia Syariah/Sharia Indonesian Bank Certificate) rate had a positive effect (significant) on the demand for Islamic insurance in Indonesia.

H4: Education had a positive effect (significant) on the demand for Islamic insurance in Indonesia.

H5: GDP per capita had a positive effect (significant) on the demand for Islamic insurance in Indonesia.

H6: Dependency Ratio had a negative effect (significant) on the demand for Islamic insurance in Indonesia. 


\section{Methods}

\section{Types and Data Sources}

The type of data used in this research was secondary data. This research used monthly secondary data from January 2014 to December 2016. The data were sourced from the Statistics of Sharia Insurance published by the Financial Services Authority, Central Bureau of Statistics, World Bank Data, Indonesian Sharia Insurance Association, and Indonesian Bank, as well as various works such as books, journals, past research, and electronic media.

\section{Processing Method}

The data analysis method used was descriptive quantitative. Analyzer used in this research was Ordinary Least Square (OLS) method. The data was processed using Eviews 8 and Microsoft Excell 2007 software.

\section{Analysis Method}

The analytical method used to analyze the effect of macroeconomic variables on the demand for Islamic insurance in Indonesia was Ordinary Least Square (OLS). Multiple linear regression method was a data analysis technique which discussed the relationship between dependent variables with independent variables. Multiple linear regression was a regression which the dependent variable was variable $Y$; in this research was the penetration of Islamic insurance in Indonesia connected to more than one independent variables. The independent variables used were money supply, inflation, SBIS rate, GDP per capita, dependency ratio, and education. Estimation equation used OLS model analyzing the influence of independent variables to a dependent variable through a model or equation used by the demand of conventional insurance to be applied to the demand of Islamic insurance. Previous research on the determination of conventional insurance demand function was conducted by Prihantoro et al. (2013). Based on the model, several macroeconomic variables influenced the demand for Islamic insurance was obtained. From the above description, the model used was:

$\operatorname{Ln}\left(\right.$ PREMI $_{t}=a+b_{1}$ Ln $(J U B)_{t}-b_{2}$ INFLASI $_{t}+b_{3}(\text { SBISRATE })_{t}+b_{4}$ PENDIDIKAN $_{t}$ $+b_{5} \operatorname{Ln}(G D P)_{t}-b_{6} D R_{t}+e$

Information:

$\mathrm{Y}$

a

$\beta$
$=$ Premium (billion)

$=$ Constants

$=$ Regression coefficient of independent variables 


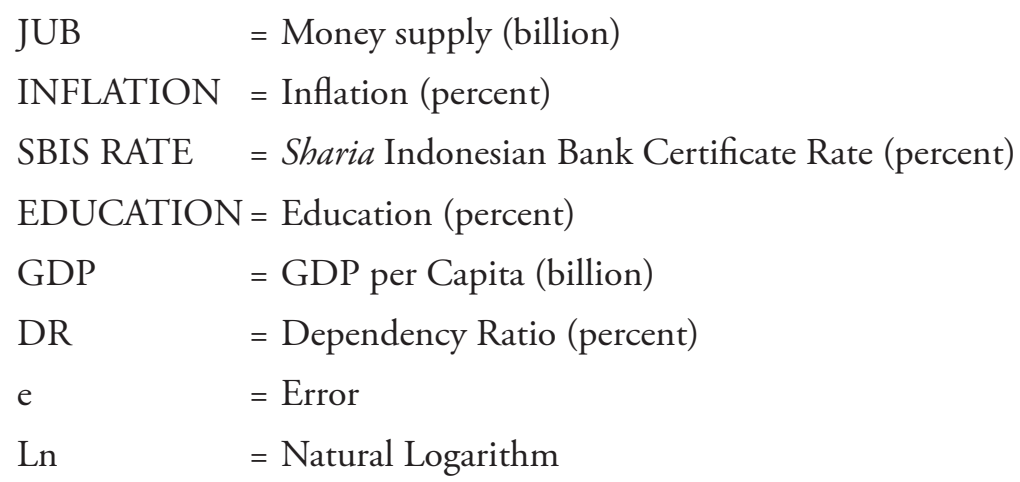

\section{Normality Test}

Normality test was a test to determine whether the variable was normally distributed or not. Normality test aimed to determine the data distribution among variables to be used in the research. Good and feasible data used in the research was data with a normal distribution. The test was used to see the data normality through JarqueBera test or by looking at the plot of the residual.

The hypothesis in the normality test was:

H0: Residuals were normally distributed

H1: Residuals were not normally distributed

The basis for $\mathrm{H} 0$ rejection was conducted by comparing the Jarque-Bera Test with a real level $\alpha$ of 0.05 , whereas the Jarque-Bera Test value was greater than the real level $\alpha=5$ percent, then there was not enough evidence to reject $\mathrm{H} 0$, so the residuals were normally distributed.

\section{Autocorrelation Test}

According to Firdaus (2011), autocorrelation was a disturbance in regression function in the form of correlation between interference factors. Autocorrelation was more likely to appear in time series data. Due to its nature, the present data was influenced by data in the previous time. A model had an autocorrelation if errors from different time periods were correlated. This autocorrelation would cause the inefficiency of model although still unbiased and consistent.

\section{Heteroscedasticity Test}

A linear regression model should have the same variance (Gujarati, 2006). If this assumption were not met, then there would be a problem of heteroscedasticity. 
The heteroscedasticity test aimed to determine whether in a regression model occurred a variant inequality of residuals for known free variables. The consequence of heteroscedasticity was the possibility to draw a false conclusion from the F-Test because of the significance level test was less powerful. The test which might be done to see this symptom was by Heteroscedasticity test.

\section{Multicollinearity Test}

Multicollinearity was a condition in which the independent variables had a correlation between one another. If the independent variables had the same correlation with one or perfectly correlated, it would result in the unpredictable coefficients, and the standard error value of each regression coefficient became infinite (Purwanto, 2011). The presence of multicollinearity could be seen through a correlation matrix, which the correlation limits between the independent variables were no more than $|0.80|$. To solve the multicollinearity problem was adding or reducing the number of observational data, increasing or decreasing the number of independent variables which had a linear relationship with other variables, and transforming the variables. In addition to the correlation matric, if there was a higher correlation value of $|0.80|$, then the multicollinearity could be ignored as long as the correlation value did not exceed the Adjusted R-squared value.

\section{Variables and Operational Definition}

a. Penetration was the total percentage of the company's sales (from all sources) with total sales of services or products in the industry.

b. The money supply was the money circulating among the public in the form of currency, current account, deposits, and savings.

c. Inflation was the process of increasing prices in general and continuous with regard to market mechanisms which caused by various factors of money expressed in percent.

d. SBIS rate was the profit-sharing rate to be paid by the Bank of Indonesia.

e. Education was a process of changing the attitude and behavior of a person or group in an effort to develop human resources through teaching and training.

f. GDP was an indicator of economic growth.

g. Dependency Ratio was the ratio between the population of 0-14 year old plus the population of 65 years and above, to the population of 15-64 year old. 
h. Macroeconomic indicators were the macroeconomic variables used in this research, such as inflation, SBIS rate, money supply, and GDP per capita.

\section{Results and Discussion}

\section{The Development of Islamic Insurance in Indonesia}

The development of Islamic insurance in Indonesia experienced a fluctuating trend. This development was different from the total assets of Islamic insurance, which experiencing an increasing trend every year. The first establishment of Islamic insurance in Indonesia was initiated by the Indonesian Association of Muslim Intellectuals (ICMI) through Abdi Bangsa Foundation, Muamalat Tbk Bank, Syarikat Tafakul Malaysia, PT Asuransi Jiwa Tugu Mandiri, Ministry of finance, as well as several Indonesian Muslim businessmen. The establishment of Islamic insurance in Indonesia was marked by the establishment of PT Syarikat Takaful Indonesia on 24 February 1994. The success of the establishment of Sharia Insurance was followed by other companies that offered similar instruments.

Figure 1. The Development of Sharia Insurance (Billion)

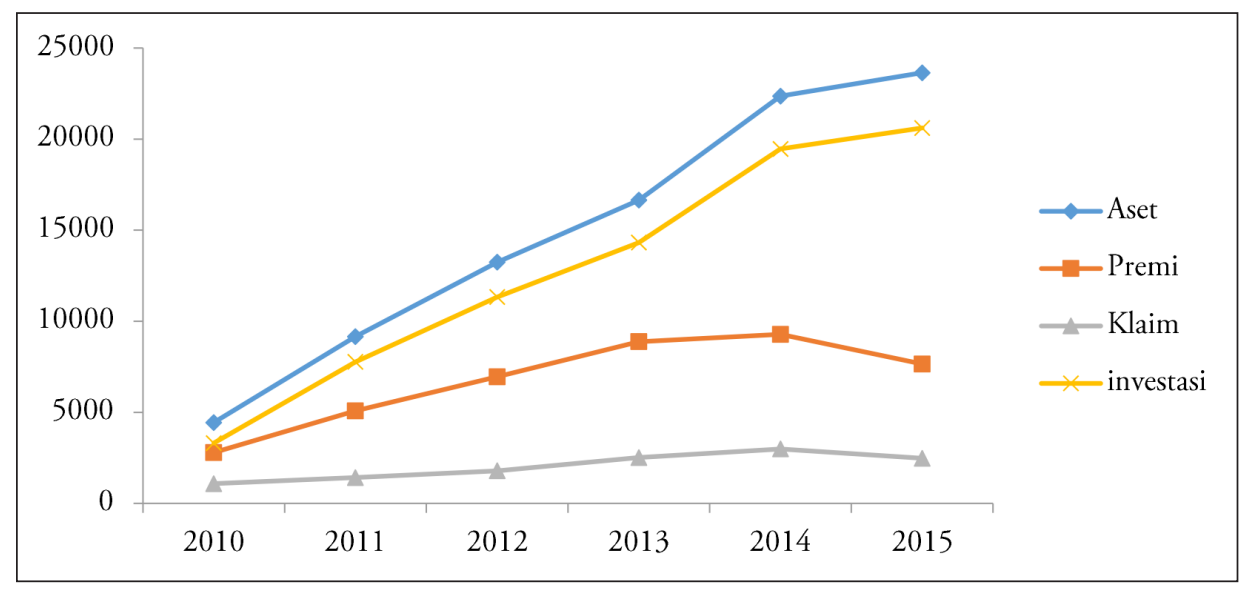

Source: AASI (2016)

Figure (1) showed the total assets, premium, claims, and investment of Sharia Insurance within five years. The total premium and investment of Sharia Insurance were continuously increasing in 2010, which reached 2790 and 3310 billion rupiahs compared to the total premium and investment in 1994. The increasing trend from the first year until the end of 2015 was in accordance 
with the growth of Islamic insurance companies in Indonesia, as was shown in (Figure 2).

Figure 2. The growth of Sharia Insurance Company in Indonesia (Unit)

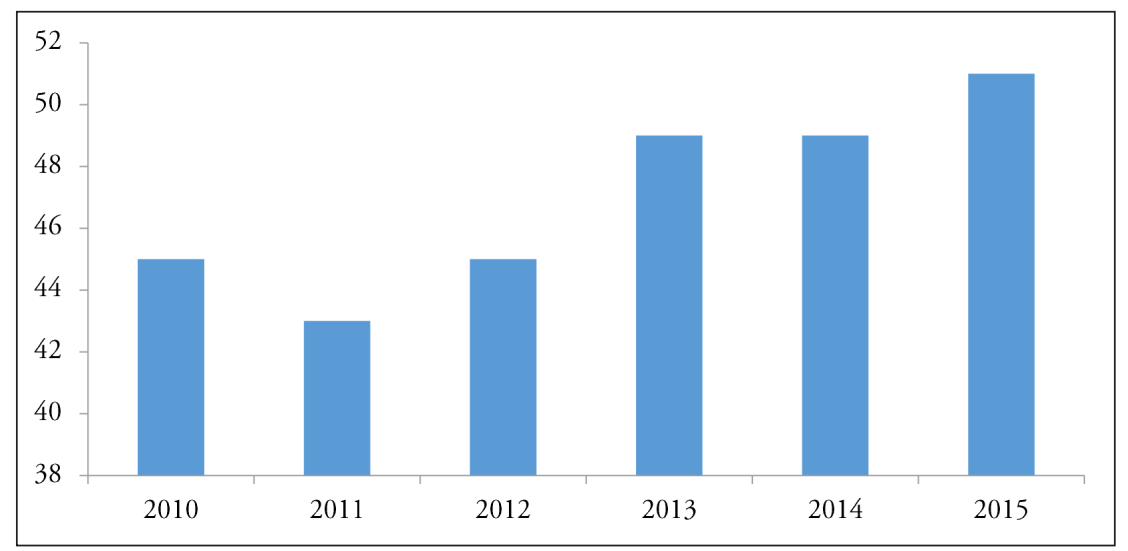

Source: Financial Services Authorities (OJK, 2016)

The development of Sharia Insurance can not be separated from various macroeconomic variables. Macroeconomics is a study about comprehensive economics, including the national income and price changes. The overall price changes or inflation will affect on the national income of various sector of institutions.

Figure 3. Inflation Rate in Indonesia (Percent)

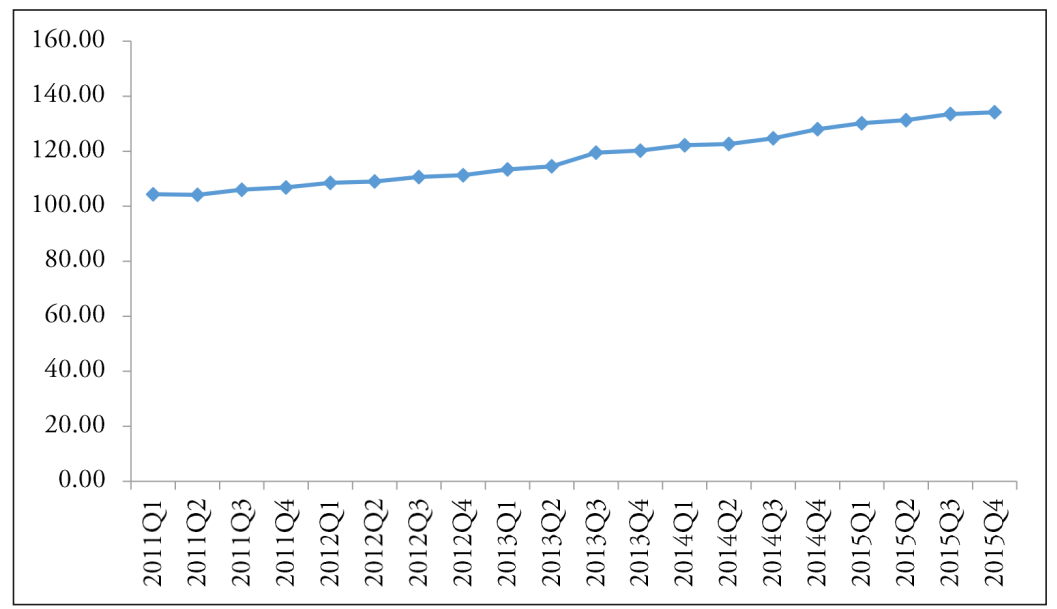

Source: Bank of Indonesia (2016) 
Inflation can give a positive and negative impact on economic growth. Inflation can give positive impact if the inflation rate less than 10 percent or can be called as minor inflation. Fig 6 shows the inflation rate from January 2014 until November 2016. The positive impact of inflation on economic growth will encourage the company to increase the production due to the increased prices. The increase in production by the company can create new jobs so it can absorb labor. The absorption of labor can affect the increase of the national income so the per capita income or the average income will increase. The increased per capita income or the average income will make the supply of the money on the public increased so that the excessive money can be used to buy the Sharia Insurance products.

In general, the amount of circulated money (money supply) from 2014 to 2016 has an increasing trend. The development of the amount of circulated money (money supply) is supported by the development of the constituent components. The positive economic activity cannot be separated from the role of the currency as one of the tools of payment in society. As the GDP (PDB) is growing, and the inflation rate is increasing, the average amount of the circulated currency (money supply) also continues increasing. The development of the amount of the circulated currency (money supply) is still seasonally patterned, marked by the increasing amount of the circulated currency (money supply) in Ramadhan, Eid Fitr and new academic year. Specifically, in Ramadhan and Islamic holidays, the number of the circulated currency (money supply) has significantly increased.

Figure 4. The Development Of The Circulated Currency (Billion)

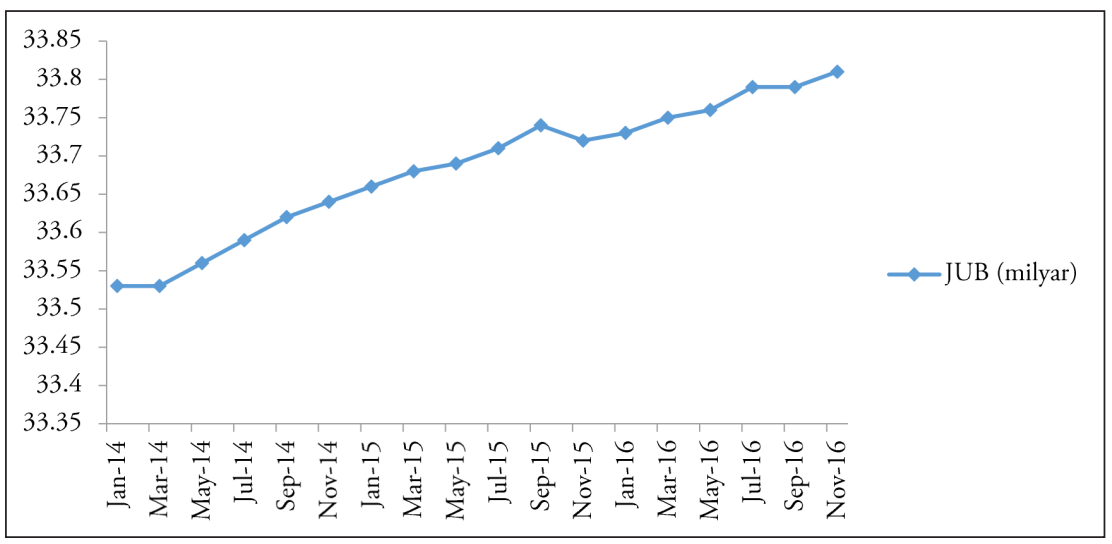

Source: The Indonesian Central Bureau of Statistics (BPS, 2016) 
In general, the movement rate of SBIS from 2014 to 2016 has experienced fluctuating development. Based on Figure (3.4), in 2014 the SBIS rate amounted to $7.5 \%$, this is based on the belief that the ratio will be lower. At the beginning of 2015, there was an increase to $7.75 \%$. The number tends to be stable due to the rising of food commodity prices and global energy as well as the relatively stable rupiah exchange rate. Then, in the last year, BI interest rate is at $4.75 \%$ level. This is caused by the normal price of fuel, so it decreases inflation.

The movement of SBIS rate tends to have the same trend with the demand for Sharia Insurance. It can be indicated that the level of SBIS rate has a positive correlation with the demand for Sharia Insurance. The high level of SBIS rate will encourage insurance companies to invest. The high level of SBIS rate will increase the profit of the insurance company so it will increase the profit obtained by insurance customers.

Figure 5. Level of SBIS Rate (Percent)

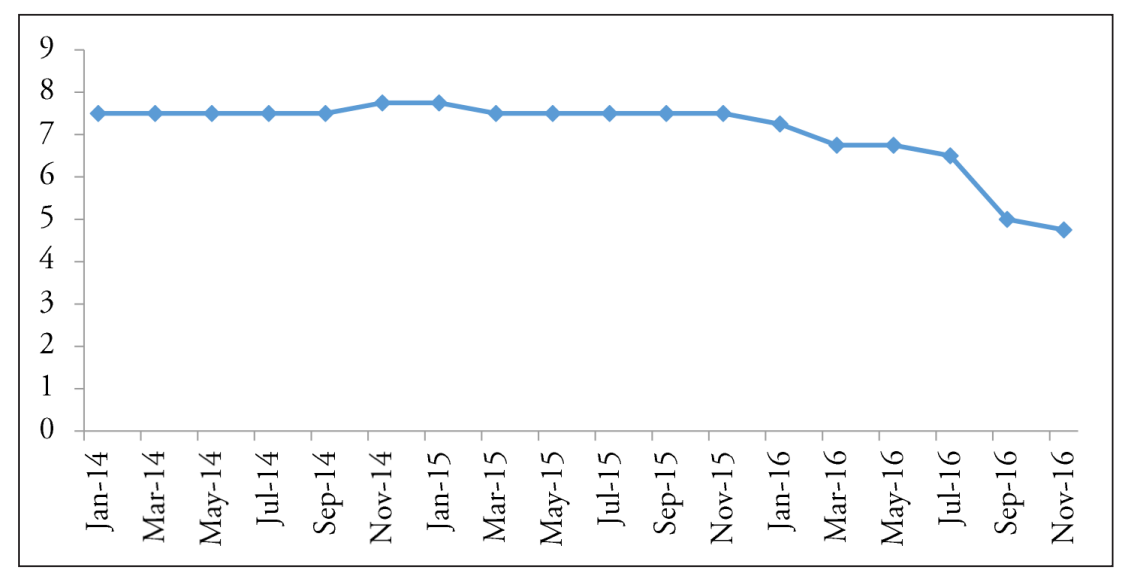

Source: Bank of Indonesia (2016)

The pace of economic growth in Indonesia has decreased in the last six years, from 2011 to 2016. This is because of the uncertainty of global financial markets, where the global economic crisis that happened in 2008-2009 still affected the world economic stability. Based on Figure (5), until 2013, the real GDP of Indonesia continues to increase. The turn from 2013 to 2014, the real GDP has experienced the most significant decrease that is amounted to $0.54 \%$. By the end of 2015 , the pace of real GDP again increases to IDR 9433034 billion. 
Figure 6. Indonesia’s real GDP for the Period 2011-2016 (Billion)

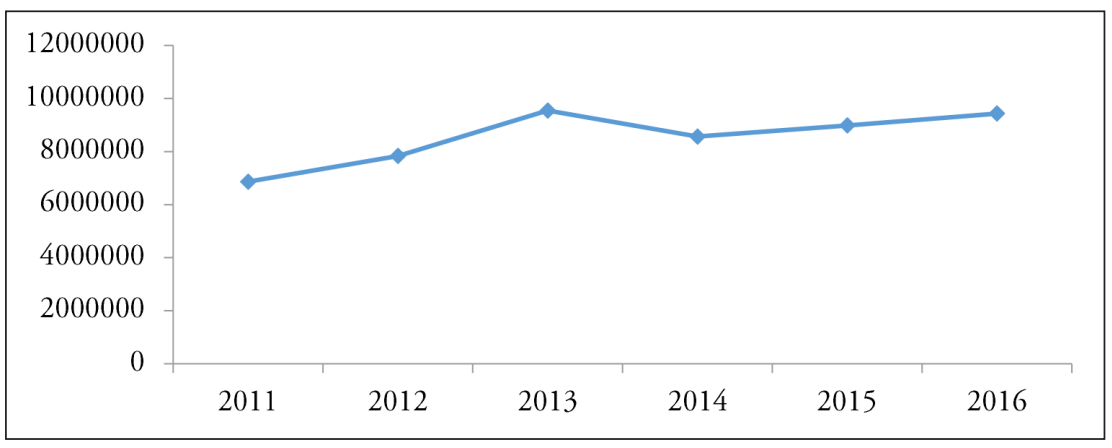

Source: The Indonesian Central Bureau of Statistics (BPS, 2016)

\section{Normality Test Results}

Normality test is conducted by using the Jarque-Bera Test, which is present in Eviews 8 Software. The result of calculation by using Eviews 8 software produces the output in Appendix 1. From the result obtained Jarque Bera value of 0.272475. This indicates that the value of Jarque-Bera is greater than the real level of 5 percent. Jarque-Bera value which is greater than the real level of 5 percent indicates the insufficient evidence to do rejection on $\mathrm{H} 0$ and indicates a normally distributed residual. Based on these results, it can be concluded that the criteria of estimation model normality have been met.

Autocorrelation Test Results

Autocorrelation testing on Eviews 8 Software can be identified through the Serial Correlation LM test, where the value of probability obs*R-squared must be greater than the critical value $(\alpha)$. The value of probability obs* $\mathrm{R}$-squared on the equation model is 0.1260 , which means it is worth greater than $\alpha=5$ percent. This shows that the equation model used in this study has no autocorrelation problem. The test results can be seen in (Table 2).

Table 2. The Result of Autocorrelation Test

\begin{tabular}{ll}
\hline Breusch-Godfrey Serial Correlation LM Test: & \\
\hline F-statistic 1.755330 & Prob. F (2,27) 0.1920 \\
Obs*R-squared 4.142283 & Prob Chi-Square (2) 0.1260 \\
\hline
\end{tabular}




\section{Heteroscedasticity Test Results}

The autocorrelation test in Eviews 8 software can be identified through the White test, where the value of probability obs*R-squared must be greater than the critical value $(\alpha)$ used. The test results show that the value of probability obs*Rsquared on the equation model is 0.1928 , which means greater than $\alpha=5$ percent. Therefore, the equation model used in this study does not have heteroscedasticity problems. The test results can be seen in (Table 3).

Table 3. The results of heteroscedasticity test

\begin{tabular}{ll}
\hline Heteroscedasticity Test: White & \\
\hline F-statistic 1.533969 & Prob. F (6,29) 0.2024 \\
Obs*R-squared 8.672887 & Prob. Chi-Square (6) 0.1928 \\
Scaled explained SS 10.97273 & Prob. Chi-Square (6) 0.1892 \\
\hline
\end{tabular}

\section{Multicollinearity Test Results}

To detect whether the model experiences multicollinearity can be seen by using the Variance Inflation Factor (VIF) for each independent variable. Multicollinearity test results show that there is no VIF value more than 10 , then it can be said that there is no correlation between independent variables. The test results can be seen in (Table 4.) below:

Table 4. Multicollinearity test results

\begin{tabular}{cc}
\hline Variable & Centered VIF \\
\hline Inflation & 2.380195 \\
JUB & 1.337391 \\
SBIS & 2.487357 \\
Education & 3.289116 \\
GDP per Capita & 1.468626 \\
DR & 2.357262 \\
C & NA \\
\hline
\end{tabular}




\section{The Stage of Model Evaluation Based on Economic Criteria}

The estimation of the model obtained from the data processing showed quite good results because it has met the requirements of model testing. Furthermore, the evaluation with economic criteria needs to be done by looking at the sign and the quantity of each independent variable. Based on the estimation result obtained through the OLS method, four variables used partially have a significant effect on the demand for Sharia Insurance in Indonesia. Table (5) presents the estimation results for each variable in the model.

Table 5. The Result of Model estimation

\begin{tabular}{lcc}
\hline \multicolumn{1}{c}{ Variable } & Coefficient & Probability \\
\hline INFLATION & $-0.310319^{* * *}$ & 0.0004 \\
LOGJUB & $0.462721^{*}$ & 0.0966 \\
SBISRATE & $0.125327^{* *}$ & 0.0019 \\
EDUCATION & $0.561183^{* *}$ & 0.0404 \\
LOGGDP & $0.246389^{* * *}$ & 0.0015 \\
DR & $-0.096244^{* *}$ & 0.0329 \\
C & $0.156179^{* *}$ & 0.0107 \\
\hline R-Squared & 0.817640 & \\
\hline Prob (F-Statistic) & 0.000000 & \\
\hline
\end{tabular}

Description: ${ }^{* * *}$ ) significant on the real level of $1 \%$

${ }^{* *}$ ) significant on the real level of $5 \%$

*) significant on the real level of $10 \%$

\section{The Effect of Inflation on the Demand of Sharia Insurance in Indonesia}

The variable of inflation has a negative and significant effect on the real level of $1 \%(\alpha=0,01)$ to the demand for Sharia Insurance in Indonesia and has a coefficient of -0.310319 . It means that, if there is an increase in inflation by one percent, it will cause the demand for Sharia Insurance decreased by 0.310 percent at a real level by 1 percent. In general, inflation can be defined as an increase in the price of goods and services as indicated by the rise in the price index of goods and services that become the reference by the Central Bureau of Statistics (BPS). The increase in the price of these goods and services will directly cause the real income level used by the people for consumption as its value decreases. The higher inflation rate will decrease 
the purchasing power of the people to the goods and services including the Sharia Insurance program. The results of this study show that inflation has a negative effect on the demand of Sharia Insurance, which means that any increase in the rate of inflation leads to a decrease in public demand of Sharia Insurance because there is a decrease in real income obtained by the public. The results of this study are in accordance with the previous research hypothesis and research conducted by Hari (2013).

\section{The Effect of Circulated Currency on the Demand of Sharia Insurance in Indonesia}

The variable of the amount of circulated money has a positive and significant effect on the real level of $10 \%(\alpha=0.1)$ to the demand of Sharia Insurance in Indonesia and has a coefficient of 0.463 . It means that, if there is an increase in the amount of circulated money (money supply) by one percent it will cause the increased demand for Sharia Insurance by 0.463 percent at the real level of 10 percent. The amount of circulated money (money supply) is positively related to the demand for Sharia Insurance. This means that the greater the amount of circulated money (money supply), then the demand for Sharia Insurance will increase. It is based on Keynes's hypothesis, that is, Money Supply has a positive effect on economic output and growth. If there is an excess of the amount of circulated money (money supply), then the Central Bank of Indonesia will take a policy to increase the interest rate. This condition will encourage people to make protection and higher investment, so this will eventually create an increase in demand for Sharia Insurance. Conversely, demand for money (money demand) will have a negative relationship to the output, increased demand for money (money demand) will have an impact on the decline in interest rates and finally resulting in decline in demand for Sharia Insurance. The results of this study in accordance with the research hypothesis and with previous research conducted by Hari (2013).

\section{The Effect of Education Level on Demand for Sharia Insurance in Indonesia}

The variable of education level has a positive and significant effect on the real level of $5 \%(\alpha=0,05)$ to the demand for Sharia Insurance in Indonesia and have coefficient 0,561 . It means that, if there is an increase in education level by one percent, it will cause the demand for Sharia Insurance increased by 0.561 percent. This indicates that the higher levels of education of the population will encourage the growth and development of insurance demand (Nestrova, 2008). According to Nesterova (2008) the higher the level of public education will directly affect the 
demand function of Syariah Insurance. The higher the level of education of a person will expand the opportunity to increase the productivity level in helping the family. Then, it will further increase the financial ability of each family to meet various needs and savings. Meanwhile, several studies have shown that the higher the levels of people education, it will increase public awareness and perceptions of the concept of benefits and risks, as well as the benefits and roles of insurance (Nesterova, 2008). It can be concluded that the level of public education will directly affect the demand function of Sharia Insurance.

\section{The Effect of GDP per Capita on the Demand of Sharia Insurance (Takaful) in Indonesia}

The variable of GDP per capita has a positive and significant effect on the real level of $1 \%(\alpha=0,01)$ to the demand for Sharia Insurance in Indonesia and have coefficient 0,246 . It means that, if there is an increase of GDP by one percent, it will cause the demand for Sharia Insurance increased by 0.246 percent at a real level of 1 percent. The effect of GDP growth on the increase in demand for Sharia Insurance is related to the indicators of the welfare of the people in the activities of expenditure and consumption. The higher level of expenditure and consumption made by the people then simultaneously encourage increased per capita income, and will further encourage the function of insurance demand. The growth of per capita income level will give the public the flexibility to manage and organize the risks so that the continuous increase of per capita income will increase the number of Sharia Insurance premium. It can be concluded that the increase in the GDP will increase the demand for Sharia Insurance (Yaari 1965, Lewis 1989; Bernheim 2001; Lind and Grace 2006; and Nesterova 2008).

\section{The Effect of SBIS Rate on Demand for Sharia Insurance in Indonesia}

The variable of SBIS Rate has a positive and significant effect on the real level of $1 \%(\alpha=0,01)$ to the demand for Sharia Insurance in Indonesia and has coefficient 0.125327 . That is if an increase in SBIS Rate of one percent will cause the demand for Sharia Insurance increased by 0.125327 percent at a real level of 1 percent. SBIS Rate is one of the main factors for Sharia Insurance companies because SBIS will reflect the amount of return investment funds that will be obtained by the company. The higher SBIS will boost the profitability of Sharia Insurance companies, and will further increase the profitability of Sharia Insurance customers. These conditions can ultimately lead to increasing demand for Sharia Insurance purchased by the public. 


\section{The Effect of Dependency Ratio on the Demand of Sharia Insurance in Indonesia}

The variable of dependency ratio has a negative and significant effect on the real level of $5 \%(\alpha=0.05)$ to the demand for Sharia Insurance

Indonesia and has a coefficient of -0.096 . It means that, if there is an increase in dependency ratio by one percent, it will cause the demand for Sharia Insurance decreased by 0.096 percent at a real level of 5\%. The level of dependency ratio gives a negative effect on the demand for Sharia Insurance. The negative effect of the dependency ratio level is because of there is dependency level in one family, so that the number of family members who do not work in one family will decrease the ability of the family to carry out various consumption of goods and services that are classified as secondary and tertiary. In addition, the high level of dependency ratio will limit the ability of the family to carry out saving and investment activities. The next impact is the lower level of people saving, which is classified as having high dependency ratio that will decrease the demand for Sharia Insurance (Prihantoro, 2013).

The high level of dependency ratio of a country or region is caused by the low value and composition of the education level of its people. The higher the level of education will expand the chances and increase the productivity level in helping the family, thus it will lower the level of dependency ratio. Whereas the effect of education level on the demand function of Sharia Insurance is indicated by the conception that, the higher the level of education of the people, it will increase the awareness and public perception to the concept and risks, as well as the benefits and the role of Sharia Insurance (Prihantoro, Basuki, and Iskandar 2013).

\section{Conclusion}

The performance of the Sharia Insurance that shows a positive trend each year indicates that the Sharia Insurance in Indonesia is experiencing a very good development in the future. The performance condition of Sharia Insurance which is quite good, is also supported by the stable macroeconomic conditions that affect the demand for Sharia Insurance in Indonesia. The variables of the amount of circulated money (money supply), GDP per capita, interest rate, education level are positively related to the demand of Sharia Insurance in Indonesia whereas the inflation and dependency ratio have negative effects. The results of OLS show that the variables of the amount of circulated money (money supply), GDP per capita, interest rate, education level, inflation, and dependency ratio have significant effects on demand for Sharia Insurance in Indonesia. The variable that has the greatest influence on the demand for Sharia Insurance in Indonesia is the level of education. Based on these 
results, the government should be advised to maintain stability of inflation in order to remain stable so that public trust in the stability of the economy is also maintained. The effect of inflation stability will increase public demand for Sharia Insurance. In addition, the amount of circulated money (money supply) is another macro variable that affects the demand for Sharia Insurance. Therefore, the government is suggested to regulate the amount of circulated money (money supply) in society which will ultimately influence the price stability or inflation in the society.

\section{References}

Asosiasi Asuransi Syariah Indonesia. 2016. Sharia Insurance Economic Outlook, 2016. Retrieved February 12, 2017. From https://aasi.go.id.

Asosiasi Asuransi Syariah Indonesia. 2016. Jumlah Perusahaan Asuransi dan Reasuransi dengan Prinsip Syaria. Retrieved February 12, 2017. from https://aasi.go.id.

Boston Consulting Group. 2016. Proyeksi Jumlah Masyarakat Kelas Menengah di Indonesia. Retrieved March 12, 2017. from https://www.bcg.com.

Bank Dunia. 2013. Populasi Masyarakat Kelas Menengah Indonesia. Retrieved February 5, 2017. from https://worldbank.org.

Beck, Thorsten. \& Ian Webb. 2003. "Economic, Demographic, and Institutional Determinants of Insurance Consumption Across Countries." The World Bank and International Insurance Foundation 17(1): 51-88.

Bernheim, B. Douglas, Katherine Grace Carman, Gokhale Jagadeesh Gokhale, and Laurence J. Kotlikoff. 2001. "The Mismatch between Insurance Holdings and Financial Vulnerabilities: Evidence from the Survey of Consumer Finances." NBER Working Paper (W8544). Retrieved from http://ssrn.com/ abstract $=287742$.

Bank Indonesia. 2005. Peraturan Bank Indonesia Nomor: 7/39/PBI/2005 Pemberian Bantuan Teknis Dalam Rangka Pembangunan Usaha Mikro, Kecil dan Menengah. Retrieved October 21, 2015. from http://www.bi.go.id.

Bank Indonesia. 2016. Inflasi. Retrieved February 5, 2017. From http://www.bi.go.id.

Bank Indonesia. 2016. M2. Retrieved February 5, 2017. From http://www.bi.go.id. Bank Indonesia. 2016. SBIS. Retrieved July 13, 2017. from http://www.bi.go.id

Badan Pusat Statistik. 2017. Jumlah Penduduk Indonesia. Retrieved March 10, 2017. From https://www.bps.go.id.

Badan Pusat Statistik. 2017. Jumlah Uang Beredar. Retrieved March 10, 2017. From https://www.bps.go.id. 
Badan Pusat Statistik. 2017. Produk Domestik Bruto. Retrieved March 10, 2017. From https://www.bps.go.id.

Djaelani Firdaus. 2015. Industri Keuangan Syariah Non-Bank. Retrieved February 5, 2017. From https://ojk.go.id.

Firdaus, Muhammad. 2011. Ekonometrika Suatu Pendekata Aplikatif. Jakarta: PT.Bumi Aksara.

Ginting. 2015. "Pengaruh Faktor-faktor Makroekonomi terhadap Permintaan Asuransi Umum di Indonesia”. Skripsi. Universitas Indonesia, Jakarta.

Hwang, Tienyu. \& Simon Gao. 2003. "The Determinants of Demand for Insurance In An Emerging Economy- the Case of China." Managerial Finance 29(5/6): 82-96.

Hwang, Tienyu \& Brian Greenford. 2005. "A Cross-Section Analysis of the Determinants of Insurance Consumption in Mainland China, Hong Kong, and Taiwan." Risk Management and Insurance. Review 8(1): 103-125.

Kasali, Rhenald. 2013. Industri Keuangan Non Bank. Retrieved February 7, 2017. from https://ojk.go.id.

Lewis, Frank David. 1989. "Dependents and The Demand for Insurance." American Economic Review 79(3): 452-466.

Lind Yijia \& Martin F Grace. 2006. "Household Life Cycle Protection: Insurance Holdings, Financial Vulnerability and Portfolio Implications." Journal of Risk \& Insurance 74(1): 141-173.

Maslow, Abraham. 2003. Motivasi dan Kepribadian. Jakarta: Midas Surya Grafindo.

Mossin, Jan. 1968. "Aspects of Rational Insurance Purchasing." Journal of Political Economy 76(4/1): 552-568.

Nesterova, Daria. 2008. "Determinants of The Demand for Insurance: Evidence from Selected CIS and CEE Countries." National University "Kyiv-Mohyla Academy".

Otoritas Jasa Keuangan. 2016. Statistik Perasuransian Syariah Indonesia. Retrieved February 5, 2017, from https://www.ojk.go.id.

Outreville, J François. 1996. "Insurance Markets in Developing Countries." Journal of Risk and Insurance 63(2): 263-278.

Ward, Damian \& Ralf Zurbruegg. 2000. "Law, Politics and Insurance Consumption in Asia." Geneva Papers on Risk and Insurance 27: 395-412.

World Bank. 2013. Indicator Dependency Ratio. Retrieved March 10, 2017. From https://data.worldbank.org.

Yaari, Menahem E., 1965. "Uncertain Lifetime, Insurance, and The Theory of the Consumer." Review of Economic Studies 32(2): 137-150. 